\title{
Andragogical Content Knowledge as a Key Component in the Training of the Instructors of Nonformal Education
}

\author{
Sri Nurhayati ${ }^{1}$ \\ ${ }^{1}$ Department of Nonformal and Continuing Education, Faculty of Education, Indonesia University of Education, \\ West Java, Indonesia \\ Correspondence: Sri Nurhayati, Jurusan Pendidikan Luar Sekolah, STKIP Siliwangi, Jl. Terusan Jenderal \\ Sudirman, Cimahi, Kode Pos: 40526, Jawa Barat, Indonesia. Tel: 22-200-0021. E-mail: srinurhayah@gmail.com
}

Received: May 27, 2014 Accepted: July 8, 2014 Online Published: January 29, 2015

doi:10.5539/ies.v8n2p219 URL: http://dx.doi.org/10.5539/ies.v8n2p219

\begin{abstract}
Currently, professionals and academics of non-formal education in Indonesia have began to question the competences of the non-formal education instructors. Non-formal education is a profession that requires knowledge (subject-content area), skill (ability to deliver content in regard to the needs of society) and programme content (the content appropriate to the condition of learners). This article mainly introduces a discussion on the Andragogical Content Knowledge in the field of non-formal education, in relation to the improvement of the instructor's competences, the author emphasises understanding the content since it is content which is the basis for any intended learning. Understanding content can lead to the development of the required character, knowledge, skills, and insightful reasoning needed in the learning process. Without the Andragogical Content Knowledge, teaching in non-formal education will become an everybody's area of specialization. Given the recent government interest in tutor/ instructor competences for the non-formal education within Indonesia, this article focuses on 'Andragogical Content Knowledge' as one way to contribute to the professionalisation of non-formal and continuing education in the country.
\end{abstract}

Keywords: non-formal education, knowledge, instructor/tutor, Andragogical Content Knowledge

\section{Introduction}

\subsection{Background}

In the recent years, the non-formal/informal education sector in Indonesia has had changes with regard to improving professional tutor competences. Government policies to improve tutor competences and their knowledge base are of positive implications to the field. However, for long, non-formal education has failed to identify that all fundamental learning has content (Illeris, 2007). Thus, Indonesia's nonformal education field faces the challenge of subject-matter content and its interaction with andragogy (or the other teaching and learning approaches) makes it more complex.

Studies on subject-content have demonstrated how orientations toward content can have a pervasive impact on a tutor's orientation toward the reform of lerarning and of teaching (Newsom \& Lederman, 2002) and (Illeris, 2007). Sai (2008) notes that "alongside these imperatives are educationists, including Bernstein (2000), Carlgen (1999), Shulman (1987), and Verloop, Van Driel, and Meijer (2001), who have written about teacher knowledge". These educationists have pointed out that, "there is no consensus about the typology, the nature or the contexts in which such knowledge operates" (Sai, 2008). In this article, the author offers a highlight on the subject-content and its interaction with andragogy and examines some literature similar to the content deemed appropriate for the educator development.

Education is a profession that requires knowledge, skill and dedication (Sai, 2008). The field requires that individuals consistently increase their overall knowledge of the education field and be accountable to society for their instruction to learners (Jo. L. Paris \& Ju. L. Paris, 2009). The teacher knowledge bases have implications to teaching and learning. There are different types of Knowledge. Shulman (1987) and Sai (2008) provide seven categories of knowledge in education. These categories include: content knowledge, curriculum knowledge, general pedagogical knowledge, pedagogical content knowledge, knowledge of learners and their characteristics, knowledge of educational contexts and knowledge of educational values. Verloop, Van Driel, and Meijer (2001) 
as quoted by Sai (2008) referred to teacher knowledge base as 'all profession-related insights that are potentially relevant to the teacher's activities'.

Carlgen (1999) and Sai (2008) suggest that, 'to understand teacher's professional knowledge, focus should be put on the nature of the teacher's work outside the classroom teaching climate. Teacher's work is categorised into three elements namely: pre-active, interactive and post-active. According to Sai, 'Pre-active work includes planning of lessons while post-active activities include assessment of the learner's work. While Ghazi et al (www.col.org/pcf6/fp/zPK1102.doc) propose that desirable instructor qualities should include: good knowledge of the subject matter, teaching expertise, some knowledge of distance education systems, warmth, enthusiasm and empathy, acquaintance with distance learning techniques, good knowledge of evaluation techniques, a constant source of inspiration, up-to-date knowledge of all the learning materials available, an ability to imagine what the students need, awareness of the students, difficulties, a skill in communication, an interest in the students \& their study progress, an ability to explain fault, and readiness at providing help. These Ghazi etal, qualities reveal that, andragogical content knowledeg is very fundamental and much needed in the present world. It is only through this approach, that the field of nonformal education can be able to meet the increasing community needs.

\section{Literature Review}

Today, the world is confronted by growing complexity of technology, making most of the people to seek retraining to upgrade their skills or prepare for entirely new careers while on the other hand, groups and individuals are pressing for new options in society, all are looking forward to education as the key sector to greater opportunity and fulfillment (Patrick, 1981). This has led to the widening of the scope of non-formal education in both the developed and developing countries (Indonesia Inclusive). There are signs that non-formal education has gained new momentum (Rogers, 2004) and (Hoppers, 2006). In many countries of the south, new programmes have been or are being launched with a view to reaching previously disadvantaged or excluded groups using non-formal approaches (Hoppers, 2006). This means, there are several forces in the developing of non-formal education programmes. Kamil, in his unpublished work reveals that the stimulus for non-formal education programmes will be determined by the development of knowledge, information \& communication technology, the development of community values or culture, social problems, economic and of course development of education. The key role of non-formal education in the future will be determined by the ability of the managers, practitioners, instructors and scholars/academicians of non-formal education. Since this paper is about the andragogical knowledge base and instructor competence development in non-formal education, the following concepts and theories are presented:

\subsection{Non-Formal Education}

According to Coombs and Ahmed (1978) non-formal education, though not a recent phenomenon, has received little attention. Yet, the demand for the trained personnel in non-formal education as an alternative of formal education is being increased throughout the world (Ghazali and associates:www.col.org). In the rural setting, for example, there are diverse and numerous educational needs, which according to Coombs and Ahmed (1978) are grouped into four:

1) General or basic education- comprising of literacy, numeracy, and an elementary understanding of science and one's environment.

2) Family improvement education- designed primarily to impart knowledge, skills and attitude, useful in improving quality of the family life, on issues of health \& nutrition, homemaking \& childcare, home repairs \& improvement and family planning among others.

3) Community improvement education- which aims at strengthening local \& national institutions and processes through instruction in such matters as local \& national government, cooperatives, community projects and the like.

4) Occupational education- it is designed to develop particular knowledge and skills associated with various economic activities and useful in making a living.

This implies that non-formal education is not only a supplement of the previous formal education of a small fraction of citizens (Combs, 1968; Hoppers, 2006) but is a more broader sub-system from the main education system which should be given priority in terms of knowledge content and professional development. The personnel of non-formal education should take the responsibility of the content which fits the learners. This is why, the author ventures into a long neglected topic in non-formal education. The reason being, there is need to establish how an instructor can master the approach and content within a short period in order to serve the 
non-formal education clientele. Because despite the increased efforts invested in formal education in the developing world, where the majority of people live in rural areas, only a meagre fraction of boys and especially girls are getting a full and effective education.

Wamaungo (2011) in his unpublished report, quoted from the non-formal and informal education perspective, notes that learning can take place almost everywhere in our communities because people are generally more aware of the importance and power of education as a tool for life improvement. This is the kind of learning which was adopted by UNESCO in the 1970s, to work as a guiding principle for reforming education at all levels and in all countries (Knapper \& Cropley, 1985). In other words, it is learning which is continuous. Through continuing education, a community can organize appropriate learning activities through formal schooling, non-formal and informal learning environments (Wamaungo, 2011). According to UNESCO (2008) and Wamaungo (2011) schools, colleges and universities cater for only a handful of children, youths and adults. Many others do not have the opportunity to aquire full education. Lifelong learning is a way to compensating for a lack of full formal schooling, giving opportunities for those who cannot continue their formal education. In such a situation, education can occur throughout a person's life through formal, non-formal and informal experiences as shown below:

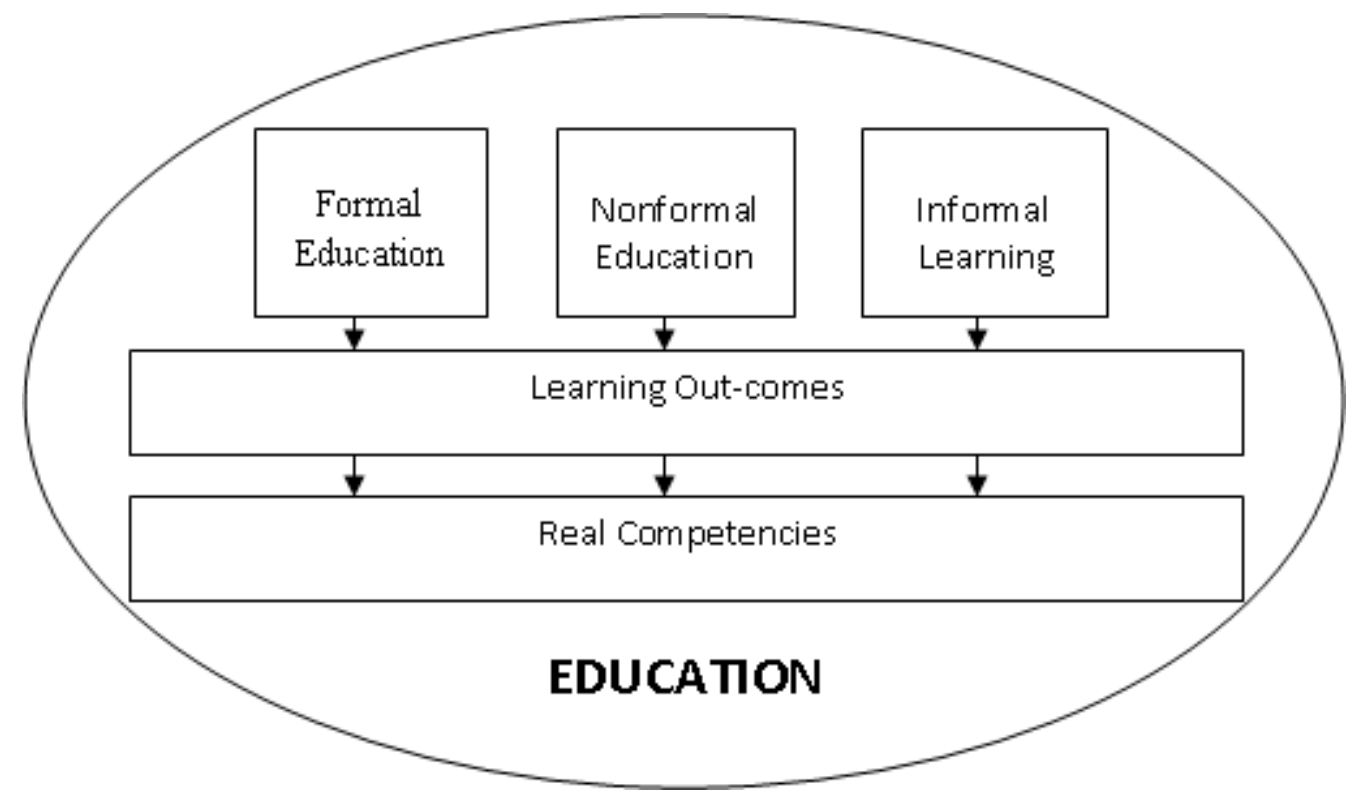

Figure 1. From formal education to informal learning: a whole education scope

Source: Wamaungo (2011) who also quotes from the Youth Forum Jeunesse.

Based on the figure above, it can be observed that education as a system is made up of three sub-sectors, namely: the formal, non-formal and informal sectors of education. According to Kamil (2007) and Wamaungo (2011), the three sectors are complementary to one another in two ways, namely: 1) In the first place, during the progression of any person's life, he or she draws on all the three sub-sectors as required for completing individual learning tasks. The three sub-sectors are integrated horizontally into an individual's personal development programme and so each contributes to continuing education. 2) Second, each type of continuing education helps and supports the other. Ideally, the system works as one body, networking to avoid high costs, redundancy, overlapping, inappropriate and/or ineffective programmes $\&$ activities.

These three sub-systems require a competent educator to be able to motivate, stimulate the learners, develop the learning materials, provide a conducive learning environment and also be able to evaluate and assess learning (Abdulhak, 2000). To size up the educational requirments of the learners in any learning setting, the educator must first have clear and realistic conception of the minimum essential learning needs (Coombs, 1973). The educator (in this case the instructor) must be able to establish a good working climate for learning in which individuals feel free to express their views openly (Phillips \& Soltis, 1998), have knowledge in order to facilitate by engaging students, understands the method or approach (in this case the Andragogy Learning Approach). This 
means, for the instructor of non-formal education to get things done smoothly, should be well versed with the content as well as the Andragogical Learning Approach.

\subsection{Knowledge}

According to Marquardt and Reynolds (1994) the world of today has moved away from the age of producing to an age of thinking organizations, from manufacturing to mento-facturing, where results come more from the mind (mento) than from the hands. Twenty years back, they predicted that the future would be dominated by "know-how" organizations (ones that require knowledge). Toffler (1970) predicted that the illiterate of the present time and of the future, will be that person who has not learnt how to learn, how to unlearn and how to relearn. Knowledge acquisition is determined by learning. Studies show that most learning theories focus on knowledge aquisition and insight, also known as cognitive learning, as the way of acquiring of information and knowledge through various kinds of cognitive activities (Marquardt \& Reynold, 1994). However, psychologists further note that gaining knowledge and insightful learning can take place, but only if educators take teaching seriously. Smith (1982) points out that a serious educator is one who will consider the following elements during the planning of an education programme:

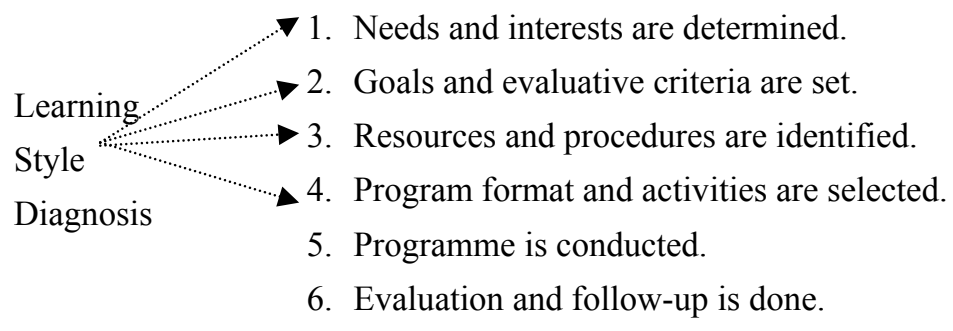

As obtained from Smith, one notes that the above illustration shows that the process through which learning takes place is influenced by other factors. These factors can only be considered by embracing a holistic approach to learning. Smiths proves that the above illustration, can be affected by other factors. This implies that an instructor in the non-formal and informal education sector should possess knowledge in this area of specialisation as well as understand the neccessary instruction techniques.

Research shows that with the increasing specialisation within many disciplines, there appears to be a growing recognition on the part of many academics (Knapper \& Cropley, 1985) including those from the non-formal education sector, the need to integrate and mantain subject-content as well as understand the approaches (moreso the Andragogical Approach to Learning). Instructors are expected to adopt broadened perspectives regarding the nature of education and how learning occurs (Gambrell et al., 1999). For instance, in the 1970s, education researchers moved from performing laboratory controlled experiments, where one aspect of learning was studied indepedent of context, to neutralistic classroom settings where contextual variables such as effective environment, authenticity of tasks, social interaction, parental involvement, or types of materials could be evaluated (Gambrell et al, 1999). Gambrell et al further point out that "simply being able to decode and answer low-level literal questions about a piece of text is no longer sufficient".

\subsection{Instruction (Instructor)}

In the Andragogical Content led approach to learning, the instructors are encouraged to understand and adapt the teaching to the content taught, the experiences of the learner and the purposes for education held by society, local communities and families (Darling-Hammond et al., 2006). A number of factors can be responsible for how quickly and effectively individual instructors learn, many of these factors are under the control of the teacher (Avis, Fisher, \& Thompson, 2010; Umar, 2013). In non-formal education, the educator arranges the condition to facilitate, rather than transmitting knowledge and skills (Darkenwald \& Merriam, 1982). Newsome and Lederman (2002) point out that, working from John Dewey's ideas about the differences in the scholarly knowledge of a discipline and the knowledge needed for teaching \& learning of that discipline, the nature \& structure of different content areas may require the use of equally different instructional approaches (Slhulman, 1987; Newsome \& Lederman, 2002).

According to Darling-Hammond et al. (2006) One that closely tracks with the programme is a framework that organises the three general areas of knowledge, skills and dispositions; they are:

First, knowledge of learners and how they learn and develop within social contexts, 
Second, conceptions of curriculum content and goals - understanding of the subject matter and skills to be taught of the social purposes of education, and

Last, understanding of teaching (instruction) in light of the content and learners to be taught, as informed by assessment and supported by productive learning environment.

Based on the three spheres pointed out above, knowledge, subject content and understanding learners and instruction is framed into two fundamental conditions for practice: teaching is a profession, meaning instructors must be ready to make decisions, in the best interest of the learners using their best available knowledge, and second, education must serve the national purpose (Darling-Hammond et al., 2006). Newsome and Lederman (2002) say that to make sense of the teaching process and to understand the influence of teachers' knowledge on instruction, it is necessary to reduce the conceptual and contextual complexity of teaching: "scholars must necessarily narrow their scope, focus their view, and formulate a question far less complex than the form in which the world presents itself in practice" (Shulman, 1986, p. 6; Newsome \& Lederman, 2002). In non-formal education, an instructor can understand the process of learning, if subject content and the Andragogy Approach are well employed.

\subsection{Andragogy Content Knowledge}

Darlin-Hammond et al. (2006) say that, knowledge needed for instruction is a judgement about what educators must be prepared to do. Hence, they therefore, emphasize that all competent educators must ensure successful learning for the learners who learn in different ways and may encounter a variety of difficulties. In other words, they must be able to diagnose and be planners who know a great deal about the learning process and have a repertoire of tools at their disposal (Hammand et al., 2006).

In relation to the above, it is therefore, clear that "Andragogical Content Knowledge" is more than just acquiring knowledge and information. It is about content and skills which can be applicable in a variety of situations, and acquiring certain types of knowledge and skills are probably essential foundations for the educators. Before an instructor can equip the learners with the neccessary abilities, and motivation to tackle real-life problems (Knapper \& Cropley, 1985) must have acquired certain competences. Indonesia's Education Act of 2005 mentions four teacher competences, which are: pedagogical competence, personal competence, social competence and professional competence (Umar, 2013).

However, for non-formal education, the competences expected are those that suit all the learners. Avis, Fisher, and Thompson (2010) propose six areas or domains, which may be interpreted as competences in the non-formal education sector: professional values \& practice, learning \& teaching, specialist learning \& teaching, planning for learning, assessment for learning and access \& progression. They further divide each of the domain into three sets of statements, relating to: professional values, professional knowledge $\&$ understanding and professional practice. The table 1 below illustrates the statements of professional values (for planning of learning):

Table 1. The statements of professional values

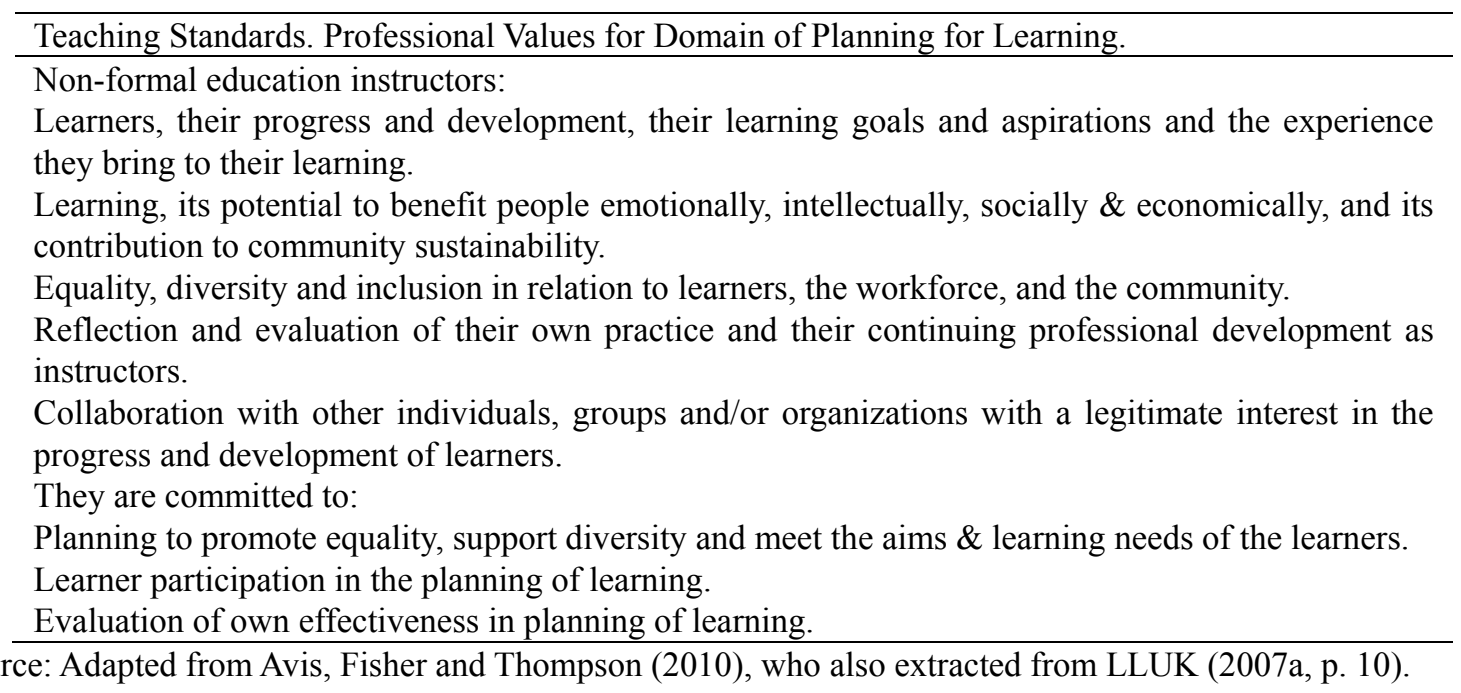


This table shows that in a non-formal setting, although the planned learning must have a design to follow (standards), it is fundamental for the instructor to recognise the contested nature of these standards and the problematic status of some elements (Avis, Fisher, \& Thompson, 2010). This is what defferentiates a qualified instructor from an amateur. The above standard can help to design better instruction standards in non-formal education learning environment. According to Avis and colleagues, such reforms can create a framework of teaching qualifications based on the standards and related to what can be seen as key teaching roles. Though Avis and Associates, write about lifelong learning from the formal school perspective, the concept has in common an approach that comprises of the Andragogical Content and framework. For instance, the table 2 below adapted from Avis, Fisher and Thompson (2010) illustrates this, it is about professional knowledge and practice (for planning for learning):

Table 2. Professional knowledge and practice

\section{PROFESSIONAL ANDRAGOGICAL PROFESSIONAL PRACTICE KNOWLEDGE AND UNDERSTANDING}

\section{Instructors in non-formal and informal Instructors in the non-formal education sector: education sector know and understand:}

\begin{abstract}
How to plann appropriate, effective, coherent and inclusive learning programmes that promote equality and engage with diversity.
\end{abstract}

How to plan an instruction and learning session.

Strategies for flexibility in planning and delivery.

2.1 The importance of including learners in the planning process.

2.2 Ways to negotiate appropriate individual goals with learners.

3.1 Ways to evaluate own role and performance in planning learning.

3.2 Ways to evaluate own role of a team in planning learning.
Plan coherent and inclusive learning programmes that meet learners' needs and programme requirements, promote equality and engage with diversity effectively.

Plan learning sessions which meet the aims and needs of individual learners and groups, using a variety of resources, including new and emerging technologies.

Prepare flexible session plans to adjust to the individual needs of the learners.

2.1 Plan for opportunities for learner feedback to inform planning and practice.

2.2 Negotiate and record appropriate learning goals and strategies with learners.

3.1 Evaluate the success of planned learning activities.

3.2 Evaluate the effectiveness of own contribution to planning as a member of a team.

Source: Adapted from Avis, Fisher and Thompson (2010), it has been modified to suit the purpose of the paper.

Table 2 is about professional knowledge and professional practices. It shows that Andragogical Content Knowledge is the integration between the mode of delivery and the content to be delivered. Studies have revealed that, within the context of an integrated program, pre-service educators can make a great deal of progress, prior to teaching and learning process, in terms of developing and integrating the domains of instructor knowledge (Krajcik et al., 1997; Starr, 1996; Zembal, 1996; Newsome \& Lederman, 2002). In regard to Table 2, an instructor should develop professional knowledge and has to understand the content, besides, must put it in practice. Andragogical Content Knowledge (content versus andragogy) is to offer opportunity to the insturctors of the non-formal and informal education service sector to apply Andragogical Knowledge to particular learning content or materials.

\section{Research Methodology}

\subsection{Research Design}

Since this study aimed at establishing an Andragogical Content Knowledge conceptual model for Instructors in the non-formal education sector, it was empirical, as well as theoretical. Six steps were involved for the study. In 
the first place, an initial assessment and analytical framework was conducted and several questions were selected. The procedure of analytical induction is employed when some specific problem, question, or issue becomes the focus of research. Data is collected and analyzed to develop a descriptive model that encompasses all cases of the phenomena. It has been used extensively in open-ended interviewing, but it can be used with participant observation and document analysis as well (Bogdan \& Biklen, 1982).

To establish an appropriate and effective model, the study-established information was reassessed and redefined on a continuous basis for a smooth study. Second, a multiple cases study was undertaken among the training instructions facilitated by Jayagiri Lembang, in Indonesia, and those condcucted by the Department of Non-formal Education of Cimahi District. A multiple approach is at times called a collective case study (Creswell, 2008; Stake, 1995). The method helped the researcher to examine the trainings conducted by the Center for the Development of Non-formal, informal and early childhood education in Jayagiri Lembang and that organised by the District Department of Non-formal and Informal Education of Cimahi District.

Third, consultations were held with the knowledgeable professionals of non-formal education in the West Java Province, especially those from the Indonesia University of Education and of course from STKIP Siliwangi. Besides, the author engaged students, moreso the doctor degree students of Non-Formal Education at Indonesia University Postgraduate School.

Fourth, the author also examined professional articles and documents of experts and professionals from Indonesia. The information obtained was then organised and arranged to make meaning out of it. By the time, the author wrote this article, the research had not been finished, however, the remaining two steps will be involved in the final report. However, a conclusion and recommendations have been generated from the existing content.

\subsection{Participants of the Study}

The first step in the process of collecting qualitative data is to identify the people and places you plan to study. This involves determining whether a researcher will study individuals or entire organizations (e.g. schools, institutions) or some combination. If a researcher selects either individuals or organizations, he or she needs to decide what type of people or organizations he or she will actually study and how many he or she will need for his or her research. These decisions require that a researcher to decide on a unit of analysis, the group and individuals he or she will study, the procedure for selecting these individuals, and assessing the numbers of people needed for his or her data analysis (Creswell, 2008; Wamaungo, 2014).

Fifteen instructors were involved in this study and were taken from the two sites for the training. They were taken from the trainings conducted at the Centre for Non-formal, Informal and Early Childhood Education Development region one, and from the district trainings of the tutors across Cimahi PKBMs. The participants were divided into groups. The participants of the study were instructors chosen from the training programmes, professionals of non-formal education and practitioners in the field. The aspects of gender were taken into consideration.

During interviews, narrations were used to clarify personal experiences and contributions in the running of the training by the training facilitators, then activities and the relevantt particles of the narrations were strictly sorted out to establish meaning. Based on the scope of the target groups, and with appropriate selected techniques, the author believes that the result has been manageable.

\section{Findings and Discussion}

This research focused on establishing the way non-formal education instructor training was conducted. The study was designed to provide the non-formal education institutions in Indonesia with information and a guide on how to develop professional instructors for the sector based on the Andragogical Content Knowledge Model. Information was gained through deep interviews, observation and several documents were examined - many of them unpublished since there is no publication on Andragogical Content Knowledge from the Indonesian perspetcive. The findings revealed that:

\subsection{Steps of the Non-Formal Education Instructor Training Programme}

The study revealed that competence-based training for instructors of non-formal education was conducted through appropriate steps. These steps included preparation phase which entailed training process design, implementation phase - which is the foundational phase in the implementation of the subject content and the Andragogical Learning Approach to training. At the implementation phase, steps of implementation are designed such that the training goes on effectively. Some instructors agreed that, "the requirements for the training are resouces mobilisation and determining of the criteria, which include content, approach to learn and the setting of 
the environment. Based on this, it was then established that one of the major components for the Andragogical Content Knowledge trainings is preparation phase because in this phase, there is selection, assessment of the participants (trainers, facilitators and the would be trainees), and also the funds are known, plus the time for the programme. The preparation phase is illustrated as in Figure 2 below:

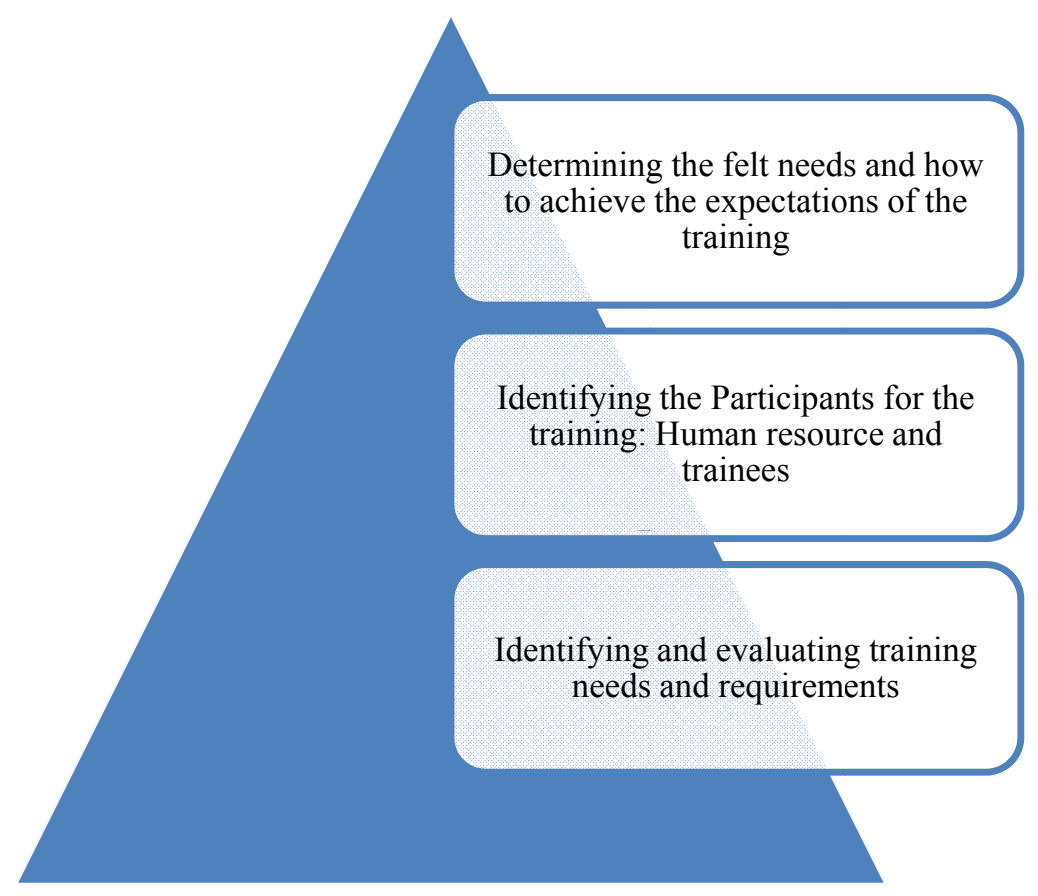

Figure 2. Prepapration phase in andragogy content knowledge setting

Currently, if any organisation is to get involved in any training programme, it should be in position to address the most immediate needs of the company, in education moreso non-formal education. The trainings offered should be relevant to the condition of the learners, so in the training there was identification and evaluation of the training needs to establish the most appropriate needs of the participants, who in turn could be in position to help their learners wherever, they come from.

Second, is the requirement crosschecking and administrative phase: During this phase, the administrative and technical issues are handled in preparation for the training: training guide, letter processing, inviations and registeration of the participants, designing of the training format and also appointing the resource personnel during the training. Some people may think that the administrative phase is a wastage of time, yet it is through management. It was discovered that good management is key to the development of instructor skills and also good learning management behaviour. The Figure 3 below illustrates the management aspect in competence development of the instructors: 


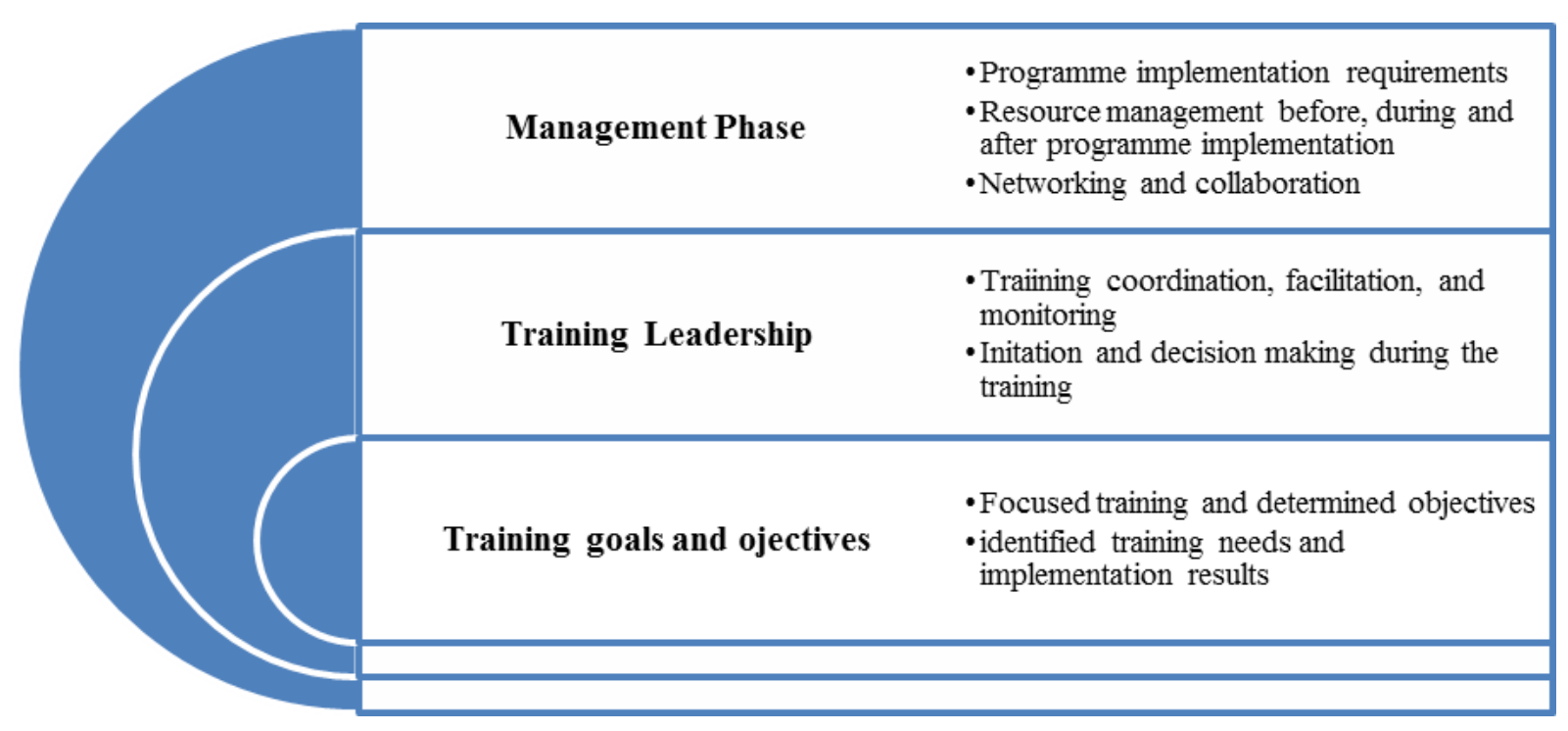

Figure 3. The management aspect in competence development of instructors

Management in training programme is about programme planning, direction and coordination (it can be summarised into implementation requirements, resource control and networking). The training itself also requires leadership and how to facilitate the learning. Besides, each trainer is a director of the training. This means, the trainings should be focused, identify objectives and implement results.

Lastly, the implementation phase, it comprised of learning professionals, learning process, assessment \& evaluation criteria and outcome. This was about the overall implementation process. During the implementation period, opportunity was given to the trainees, such that they thought of becoming self-regulated during service delivery (leading to outcome). At this level, Andragogical Content Knowledge training was explained, to help simplify the process of training implementation. It was based on the fact that for all this long in Indonesia, most trainings for non-formal, informal and early childhood trainings were lacking on the side of subject matter content (cognitive aspect), this made collaboration between understanding of the content and the instructor approaches to teaching and learning complicated. They, therefore, coined a word "Andragogical Content Knowledge" meaning "establishing content, understanding it, and delivering it appropriately to a given group of people".

The phase therefore entailed; content identification, content presentation, mode of delivery and an illustration of expected outcomes. Newsome and Lederman (2002) also extracted from (Krajcik et al., 1997; Starr, 1996; Zembal, 1996) pointed out that, "within the context of an integrated programme, pre-service educators can make a great deal of progress, prior to teaching and learning process, in terms of developing and integrating the domains of instructor knowledge about professional knowledge and professional practices. It shows that Andragogical Content Knowledge is the integration between the mode of delivery and the content to be delivered. It, therefore, implies that an instructor should develop professional knowledge and has to understand the content, besides, must put it in practice.

\subsection{Knowledge Content Divisions}

Knowledge content divisions is one of the challenges faced by the non-formal experts since it is known that non-formal instructors are professionals in the instruction methods and approaches but are limited on the part of content. However, in this study, it was established that content is given priority, the instructors are expected to understand what they facilitate in order to make appropriate decisions. It was, therefore, established that content classification is improtant, they categorised it into subject matter content, Andragogical Content, and programme content, differentiating it from the pedagogy one. This was categorised as the domain of non-formal and informal education "educator-required knowledge". Making it different from the "Teacher Knowledge", which has the basis in pedagogy which is the "art of teaching children", while the "Educator-Required Knowledge" has its origin Malcolm's andragogy which is the "art of helping adults learn", but in this case, it is a major domain to differentiate formal schooling teaching from the non-formal and informal education approaches to the instruction process. 


\subsection{Designing an Andragogical Based Training}

The training started with planning which entailed needs identification, preparing for the training, implementation phase, and a comprehensive assessment $\&$ evaluation (formative, summative and self-assessment $\&$ evaluation by the instructors), and also testing method. Andragogical Content Knowledge (content versus andragogy) is to offer opportunity to the insturctors of the non-formal and informal education service sector to apply Andragogical Knowledge to particular learning content or materials.

The findings revealed the trainings were successful, many of the participants attained the neccessary skills which helped to change their way of performance while at work. The results were revealed based on the comments and the way these participants were finding work easier than before at their places of work. Most of the instructors improved in the way they conduct teaching while in a learning environment, they were able to reflect on their actions, frame learning problems and propose \& enact effective solutions. According to Darling-Hammond et al (2006) if learning to think like a teacher is central to teacher knowledge, so is being able to act effectively on the teaching and learning insights.

An integration content and andragogy is a special case which aims at providing instructors with a specific content knowledge whereas helping instructors identify the most important approach to professional service delivery. It is this way that non-formal and informal education can be proud of professionalim, differentiating the graduates from the other professionals. In point 2.4, it is stated that "Andragogical Content Knowledge" is more than just acquiring knowledge and information. It is about content and skills which can be applicable in a variety of situations and acquiring certain types of knowledge \& skills are probably essential foundations for the educators. Before an instructor can equip the learners with the neccessary abilities and motivation to tackle real-life problems (Knapper \& Cropley, 1985) must have acquired certain competences. This is what defferentiates a qualified instructor from an amateur. According to Avis and colleagues, a prevailing model can reform teaching qualifications based on the standards and related to what can be seen as key teaching roles. In the case of this study, the Andragogical Content Knowledge is the integration between the mode of delivery and the content to be delivered. Just like Thompson (2010), proposes six areas or domains, which may be interpreted as competences in the non-formal education sector: professional values \& practice, learning \& teaching, specialist learning \& teaching, planning for learning, assessment for learning and access \& progression. In this research, the author came up with three domains, the Figure 4 below is an illustration of Andragogical Content Knowledge Model:

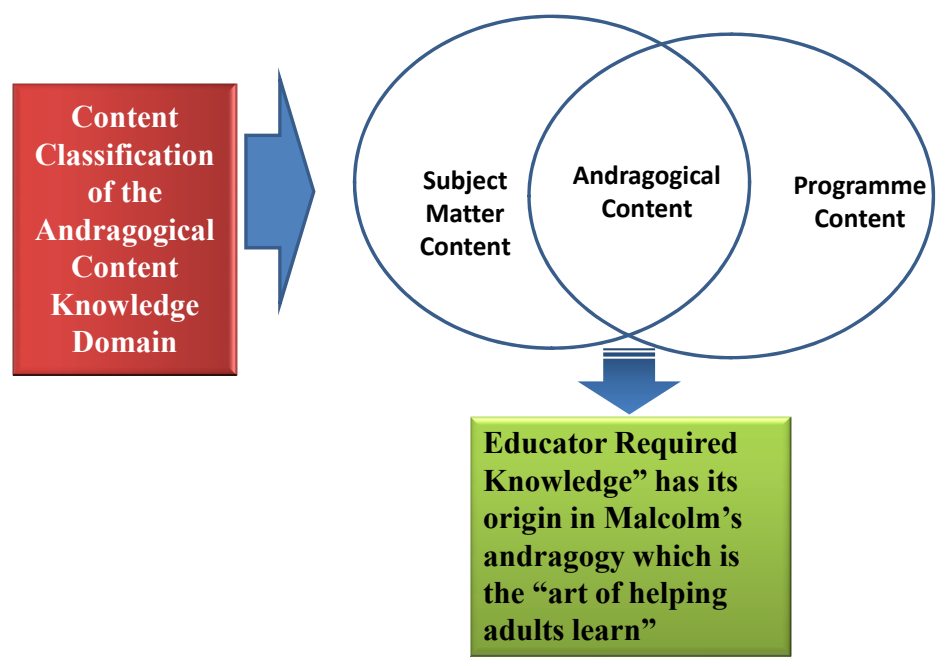

Figure 4. Andragogical Content Knowledge model 
To become a better professional, non-formal education has to come up with new creations. In this research, the creation is about content delivered and mode of delivery and who delivers the given content and how (?). The Model is named as the New Andragogical Content Knowledge since this area is still limited in discussion, though there are few writings which have come-up. The author categorises the domains into three: the subject matter content, the andragogical content and programme content. This is developed based on the training but it is in relation to the andragogy approach coined by Malcolm knowles but with modifications to fit the current development.

\section{Conclusion}

Just like the author anticipated in the abstract to the article, currently, professionals and academics of non-formal education in Indonesia have for a long time questioned the competences and professionalism of the non-formal education graduates. Non-formal education is a profession that has missed out on the area of the specific knowledge (subject-content area), skill (ability/competences) and curriculum (specified design or programme). This article mainly introduces a discussion on the Andragogical Content Knowledge in the field of non-formal education. In relation to the improvement of the instructor's competences, the author emphasises understanding the content, since it is content which is the basis for any learning. Understanding content can lead to the development of the required character, knowledge, skills, and insightful reasoning needed in the learning process. It is, therefore, on this background, that a study has been conducted, clarifying on the specifics of the Andragogical Content Knowledge as a new area for the professionals and well-wishers for the field. It is still lacking and needs a lot, if it is to match other fields.

\section{Acknowledgements}

It has been indeed tiring to venture into a new area which is still limited in conceptualisation and research. However, it has also been a new experience to me, I hope that it will be a self motivator to keep growing and exploring more in the redefinition of the concept of Andragogical Content Knowledge. I wish to thank Madam Novi Widiasituti, she has been very supportive and of help in refining the concept. I also thank Professor Mustofa Kamil, and Professor Engking S. Hassan for introducing me to such a wonderful and virgin area of study in non-formal education. I only pray that God Blesses you all! I hope that this writing is of use and can contribute to new knowledge.

\section{References}

Cahyana, A. (2010). Education Development in Indonesia. Jakarta: Widya Aksara Press.

Carlgen, I. (1999). Professionalism and Teachers as Designers. Journal of Curriculum Studies, 31(1), 43-56. http://dx.doi.org/10.1080/002202799183287

Combs, P. H., \& Ahmed, M. (1971). Attacking Rural Poverty: How the Non-formal Education Can Help. Baltimore: John Hopkins University Press.

Darling-Hammond et al. (2006). Powerful Teacher Education: Lessons from Examplary Programs. United States of America: Jossey-Bass, Wiley Imprint.

Ghazi, A. S. et al. (2014). Assessing the Needs of Literacy personnel in Non Formal Basic Education. Retrieved from http://www.col.org/pcf6/fp/zPK1102.doc.

Hoppers, W. (2006). Nonformal Education and Basic Education Reform: Conceptual Review. International Institute for Educational Planning.

Illeris, K. (2007). How We Learn: Learning and non-learning in School and beyond. USA and Canada: Routledge

Knowles, S. M. et al. (1984). Andragogy in Action: Applying Modern Principles of Adult Learning. United States of America: Jossey-Bass Inc, Publishers.

Newsome, G. J., \& Lederman, G. N. (2002). Examining Pedagogical Content Knowledge: The Construct and Its Implications for Science Education. Springer. http://dx.doi.org/10.1007/0-306-47217-1

Paris, Jo. L., \& Paris, Ju. L. (2009). Praxis II: Fundamental Subjects Content Knowledge (0511). Canada: Wiley Publishing. Inc.

Patrick, G. B. (1981). Planning Better Programs. McGraw-Hill Book Company.

Rogers, A. (2004). Non-Formal Education: Flexible Schooling or Participatory Education. Springer

Sai, L. (2008). Teaching knowledge, work-based learning and life experiences. Paper presented at the British 
Educational Research Association Annual Conference, Heriot Watt University, Edinburgh, 3-6 September 2008. Retrieved from http://www.leeds.ac.uk/educol/documents/174496.doc

Shulman, L. S. (1987). Knowledge and Teaching: Foundations of the New Reform. Harvard Educational Review, $57(1), 1-22$.

Smith, M. R. (1982). Learning How to Learn: Applied Theory for Adults. Great Britain: Open University Press, Milton Keynes.

Toffler, A. (1970). The Future Shock.

UNESCO. (1993). Continuing Education: New Policies and Directions. UNESCO Principle Office for Asia and the Pacific Bangkok.

\section{Copyrights}

Copyright for this article is retained by the author(s), with first publication rights granted to the journal.

This is an open-access article distributed under the terms and conditions of the Creative Commons Attribution license (http://creativecommons.org/licenses/by/3.0/). 